\title{
Correlation And Path Analyses of Yield and Its Component Traits in Pigeonpea [Cajanus cajan (L.) Millsp.]
}

\author{
S. Lakshmi Narayanan*, N. Manivannan and A. Mahalingam \\ National Pulses Research Centre, Tamil Nadu Agricultural University, Vamban Colony - \\ 622303, Pudukkottai District, Tamil Nadu, India \\ *Corresponding author
}

\section{A B S T R A C T}

\begin{tabular}{|c|}
\hline Keywords \\
\hline $\begin{array}{l}\text { Redgram, } \\
\text { Pigeonpea, } \\
\text { Correlation, Path } \\
\text { analysis, Seed yield }\end{array}$ \\
\hline Article Info \\
\hline $\begin{array}{l}\text { Accepted: } \\
\text { 07 February } 2018 \\
\text { Available Online: } \\
10 \text { March } 2018\end{array}$ \\
\hline
\end{tabular}

Keywords

Redgram,

Pigeonpea,

Correlation, Path analysis, Seed yield

\section{Introduction}

Pulses are the major source of proteins and are consumed worldwide to meet the protein requirement of the growing population. It is an important leguminous crop of tropics and subtropics occupying an important position in rainfed agriculture. Among the leguminous crops, pigeonpea [Cajanus cajan (L.) Millsp.] is a predominant crop grown and consumed in India. India is the largest producer and processor of pulses in the world (www.indiamicrofinance.com). Pigeonpea is the second most important pulse crop next to chickpea in India. Out of the total production of pulses (221 lakh tonnes), 19.14 per cent share (42.3 lakh tonnes) is from pigeonpea (Directorate of Economics and Statistics, 2016-17 - Second advance estimate).

A complete understanding of the correlation between yield and yield components is a must for a plant breeder towards the improvement of any crop. Similarly path analysis determines the direct and indirect effects of these characters towards the yield. As emphasized by Pandey et al., (2015) the optimum combination of yield contributing traits can be accumulated in a particular genotype only by understanding the inter relationships of various traits using correlation and path coefficients. Seed yield is a 
dependant character and whenever plant breeder goes for selection for yield it always misleads because it depends on various characters and to some extent to the environmental conditions (Bal Chinmayee, 2016). An attempt has been made in this study to know the relationship between yield and different yield attributing characters and their direct and indirect effects on yield in pigeonpea.

\section{Materials and Methods}

A total of 21 pigeonpea cultures were utilised for the present study. The experiment was conducted in the farm of National Pulses Research Station, Vamban, Pudukkottai, Tamil Nadu during kharif 2016. The genotypes were raised in randomized block design with three replications. A spacing of $0.9 \mathrm{~m}$ between rows and $0.25 \mathrm{~cm}$ between plants were maintained in a plot of size $5 \mathrm{~m} \mathrm{x}$ $4 \mathrm{~m}$. All the recommended agronomic practices were strictly followed. Observations were recorded from five randomly selected plants in each replication for each genotype for characters viz., plant height $(\mathrm{cm})$, days to 50 per cent flowering, days to maturity, number of branches, number of pods per plant, 100 seed weight $(\mathrm{g})$ and seed yield per plant. The data were subjected to statistical analysis viz., correlation and path analysis as per the standard procedure. Data obtained were subjected to correlation and path coefficient analysis using statistical software TNAUSTAT statistical package (Manivannan, 2014).

\section{Results and Discussion}

Results of correlation analysis were presented in Table 1. Genotypic correlation will provide the genotypic association between different yield attributing traits and helpful for the plant breeders to correctly identify the appropriate traits.
Seed yield was found to be significantly and positively correlated with number of branches, number of pods per plant and days to 50 per cent flowering.

Similar findings were reported by Mahendran (2011), Saroj et al., (2013), Katiyar et al., (2004) and Kesh Ram et al., (2016). Positive and significant association of number of pods per plant with seed yield shows that it proves to be a vital character affecting final grain yield as corroborated by the report of Ganesamurthy and Dorairaj (1990).

Plant height had significant and positive association with days to 50 per cent flowering, days to maturity at genotypic level. It had a significant but negative association with 100 seed weight and number of branches per plant. Significant positive correlation was observed between pods per plant and days to 50 per cent flowering and days to maturity.

Days to 50 per cent flowering had significant and positive correlation with days to maturity. However 100 seed weight had significant and negative association with days to 50 per cent flowering and days to maturity. Hence it may be concluded that number of pods, number of branches, days to 50 per cent flowering and days to maturity are the important selection indices for seed yield based on correlation. Though 100 seed weight has no influence on seed yield, due to the negative association with days to 50 per cent flowering and days to maturity it should be given due importance during selection for high yield. Significant relationship between days to 50 per cent flowering and number of pods per plant, days to maturity, seed yield will help in improving the genotypes for selecting towards higher seed yield.

This study was in accordance with Sodavadiya et al., (2009), Linge et al., (2010), Prasad et al., (2013), Kesh Ram et al., (2016). 
Table.1 Genotypic correlation coefficients of yield and yield contributing characters

\begin{tabular}{|c|c|c|c|c|c|c|c|c|}
\hline Characters & & $\begin{array}{l}\text { Plant height } \\
(\mathrm{cm})\end{array}$ & $\begin{array}{l}\text { No. of } \\
\text { branches }\end{array}$ & $\begin{array}{c}\text { No. of } \\
\text { pods/plant }\end{array}$ & $\begin{array}{c}\text { Days to } 50 \% \\
\text { flowering }\end{array}$ & $\begin{array}{l}\text { Days to } \\
\text { maturity }\end{array}$ & $\begin{array}{c}100 \text { seed } \\
\text { weight }(\mathrm{g})\end{array}$ & $\begin{array}{c}\text { Seed yield } \\
\text { per plant }(\mathrm{g})\end{array}$ \\
\hline \multirow[t]{2}{*}{ Plant height (cm) } & $\mathrm{G}$ & 1.0000 & $-0.5071^{*}$ & 0.3662 & $0.9031 * *$ & $0.7775^{* *}$ & $-0.5039 *$ & 0.2776 \\
\hline & $\mathrm{P}$ & 1.0000 & 0.3449 & $0.6787 * *$ & $0.6762 * *$ & $0.5672 * *$ & -0.3849 & $0.5546 * *$ \\
\hline No. of branches & $\mathrm{P}$ & & 1.0000 & $0.7305^{* *}$ & 0.0861 & 0.1853 & 0.0060 & $0.7609 * *$ \\
\hline No. of pods/plant & $\mathrm{G}$ & & & 1.0000 & $0.6421 * *$ & $0.6372 * *$ & -0.2907 & $0.9081 * *$ \\
\hline Days to $50 \%$ flowering & $\mathrm{P}$ & & & & 1.0000 & $0.9025^{* *}$ & $-0.4687 *$ & 0.4178 \\
\hline \multirow[t]{2}{*}{ Days to maturity } & G & & & & & 1.0000 & $-0.4872 *$ & $0.6594 * *$ \\
\hline & $\mathrm{P}$ & & & & & 1.0000 & $-0.4785^{*}$ & 0.3948 \\
\hline \multirow[t]{2}{*}{100 seed weight $(\mathrm{g})$} & $\mathrm{G}$ & & & & & & 1.0000 & -0.3459 \\
\hline & $\mathrm{P}$ & & & & & & 1.0000 & -0.2352 \\
\hline
\end{tabular}

*, ** Significant at 5 and $1 \%$ level respectively

$\mathrm{G}$ and P -Genotypic and phenotypic correlation coefficients respectively

Table.2 Direct effect, indirect effect and genotypic correlation of yield-related traits with yield of Cajanus cajan (L.) Millsp

\begin{tabular}{|l|c|c|c|c|c|c|c|}
\hline \multicolumn{1}{|c|}{ Traits } & $\begin{array}{c}\text { Plant height } \\
(\mathbf{c m})\end{array}$ & $\begin{array}{c}\text { No. of } \\
\text { branches }\end{array}$ & $\begin{array}{c}\text { No. of } \\
\text { pods/plant }\end{array}$ & $\begin{array}{c}\text { Days to 50\% } \\
\text { flowering }\end{array}$ & $\begin{array}{c}\text { Days to } \\
\text { maturity }\end{array}$ & $\begin{array}{c}\text { 100 seed } \\
\text { weight }(\mathbf{g})\end{array}$ & $\begin{array}{c}\text { Genotypic correlation } \\
\text { with seed yield per plant }\end{array}$ \\
\hline Plant height $(\mathbf{c m})$ & $\mathbf{- 0 . 3 4 6 5}$ & -0.1298 & 0.2422 & 0.8376 & -0.3986 & 0.0728 & 0.2776 \\
\hline No. of branches & 0.1757 & $\mathbf{0 . 2 5 6 0}$ & 0.1625 & 0.1440 & -0.1932 & -0.0048 \\
\hline No. of pods/plant & -0.1269 & 0.0629 & $\mathbf{0 . 6 6 1 3}$ & 0.5955 & -0.3267 & 0.0420 & $0.5402 *$ \\
\hline Days to 50\% flowering & -0.3129 & 0.0397 & 0.4246 & $\mathbf{0 . 9 2 7 4}$ & -0.4717 & 0.0688 \\
\hline Days to maturity & -0.2694 & 0.0965 & 0.4214 & 0.8533 & $\mathbf{- 0 . 5 1 2 7}$ & 0.0704 & $0.6759 * *$ \\
\hline 100 seed weight $(\mathbf{g})$ & 0.1746 & 0.0085 & -0.1923 & -0.4421 & 0.2498 & $\mathbf{- 0 . 1 4 4 4}$ \\
\hline
\end{tabular}

Residual effect: $0.1366 ; *$ ** Significant at 5 and $1 \%$ level respectively 
Path coefficient analysis reveals the partitioning of correlation coefficients into direct and indirect effects and gives a more realistic relationship of the characters and helps in identifying the effective components. In the present investigation, path analysis was carried out using genotypic correlation of component traits on seed yield per plant. The characters viz., number of pods per plant and days to 50 per cent flowering showed high and positive direct effect on seed yield per plant and it was positive and moderate in case of number of branches. The direct effect of plant height and days to maturity seems to be high but in negative direction (Table 2). This clearly indicates that seed yield can be improved by resorting to selection for all these traits. The relationship of number of pods with yield was also studied by Francis (2003), Baskaran and Muthiah (2007), Thanki and Sawargaonkar, (2010), Mahendran (2011), Rao et al., (2013), Kesha ram et al., (2016) and they reported high positive direct effect of number pods per plant Among the traits, 100-seed weight alone had low and negative direct effect on seed yield per plant. It indicated that this trait is not an important trait for seed yield improvement programme. The traits number of pods per plant and days to flowering has moderate to high and positive indirect effects via other traits. The traits days to maturity has moderate to high and negative indirect effects via other traits on seed yield per plant. Hence based on path analysis, plant height, number of pods per plant, days to $50 \%$ flowering and days to maturity should be given importance in seed yield improvement programme.

\section{References}

Bal Chinmayee P., 2016. Evaluation of Early Genotypes of Pigeon pea (Cajanus cajan (L.) Millsp.). M.Sc. Thesis. Dr. Balasaheb Sawant Konkan Krishi Vidyapeeth, Dapoli. Pp. 139.
Baskaran, K. and Muthiah, A.R. 2007. Influence of parents and their habit on genetic diversity among hybrids of pigeonpea (Cajanus cajan (L.) Millsp.). Madras Agric. J., 95 (1-6): 32-37.

Dewey, D.R. and Lu, K.H. 1959. A correlation and path coefficient analysis of components of crested wheat grass seed production. Agronomy Journal, 51: 515-518.

Francis, K. 2003. Correlation and path analysis for yield and yield components in pigeonpea (Cajanus cajan L. Millsp.). Pakistan J. Bio. Sci. 6: 16891694.

Ganesamurthy, K. and Dorairaj, M.S. 1990. Character association in Pigeonpea (Cajanus cajan (L.) Millsp.). Madras Agric. J. 77: 5-6.

Kesha Ram, Saxena Kanak, M. Shrimali Tushar and Bisnoi Geeta. 2016. A Study on Genetic Variability, Correlation and Path Analysis in Pigeon pea [Cajanus cajan L. Millspaugh]. International Journal of Agriculture Sciences, ISSN: 0975-3710 \& E-ISSN: 0975-9107, Volume 8, Issue 51, pp.-2287-2289.

Linge S.S., H.V. Kalpande, S.L. Sawargaonlar, B.V. Hudge and Thanki H.P. (2010) Electronic J. Plant Breed, 1(4), 929-935.

Mahendran. 2011. Morphological and Biochemical Characterization of Short Duration Pigeonpea (Cajanus cajan (L.) Millsp) Genotypes. Ph.D. Thesis. Tamil Nadu Agricultural University, Madurai.

Manivannan, N. (2014). TNAUSTATStatistical package. Retrieved from https://sites.google.com/site/tnaustat.

Pandey, P., V.R. Pandey, D.K. Tiwari and Yadav, S.K. 2015. Studies on Direct Selection Parameters for Seed Yield and Its Component Traits in Pigeonpea (Cajanus cajan (L.) Millsp.). Afr. J. Agric. Res. Vol 10 (6), pp 485-490. 
Prasad Y., K. Kumar and Mishra S.B. 2013 Studies on Genetic Parameters and Inter-Relationships among Yield and Yield Contributing Traits in Pigeonpea [Cajanus cajan (L.) Millsp.] The bioscan, 8(1), 207-211.

Rao, P. J. M., S. Malathi, D.V.V. Reddy, and Upender, M. 2013. Genetic studies of Association and Path Coefficient Analysis of Yield and its Component Traits in Pigeon Pea. Intl. J. of scientific and Res. Publications, 3(8).

Singh, R.K., and Chaudhary, B.D. (1985). Biometrical methods in quantitative analysis. Kaljuni Publishers, India.

Sodavadiya M.S., J.J. Pithia, A.G. Savaliya and Korat V.K. 2009. Studies on
Characters Association and Path Analysis for Seed Yield and its Components in Pigeonpea (Cajanus cajan (L.) Millsp.) Legume Research, 32(3), 203-205.

Thanki, H. P. and Sawargaonkar, S.L. 2010. Path coefficient analysis in pigeonpea (Cajanus cajan L. Millsp.). Electronic Journal of Plant Breeding, 1(4): 936939.

Udensi, $\mathrm{O}$ and Ikpeme, E.V. 2012. Correlation and Path Coefficient Analyses of Seed Yield and its Contributing Traits in Cajanus cajan (L.) Millsp. American Journal of Experimental Agriculture. 2(3): 351358

\section{How to cite this article:}

Lakshmi Narayanan, S., N. Manivannan and Mahalingam, A. 2018. Correlation and Path Analyses of Yield and its Component Traits in Pigeonpea [Cajanus cajan (L.) Millsp.]. Int.J.Curr.Microbiol.App.Sci. 7(03): 614-618. doi: https://doi.org/10.20546/ijcmas.2018.703.073 